\title{
QUR'ANIC PERSPECTIVES ON CARING FOR THE ELDERLY
}

\author{
Zamakhsyari bin Hasballah Thaib \\ Fakultas Agama Islam, Universitas Dharmawangsa \\ Jl. KL. Yos Sudarso no. 224 Medan, Sumatera Utara, 20115 \\ E-mail: dr.zamakhsyari@dharmawangsa.ac.id
}

\begin{abstract}
This article aims to describe the amount of attention that the Qur'ân has given to the problems of caring for the elderly. The author examined this topic using thematic interpretation methods by collecting $\hat{a} y a h s$ that are closely related to keywords in the study, according to the induction (istiqrâ') method. Among the main conclusions in this paper, there were many words used in the Qur'ân which refer meaning of elderly such as al-kibar, 'ajûz, syeikh, arzal al-'umr, wahana al-'azhm, dha'f, and syaibah and their derivations. Al-Qur'ân suggests that old age is an extended period; there are ordinary elderly and late elderly, each has different characteristics. In caring for the elderly, several Qur'ânic principles should always be considered, among them; glorifying and honouring the elderly is one of the main characteristics of Islamic society. It is hoped that through these qur'ânic principles, care and respect for the elderly will be better among the Muslim community, especially in Indonesia.
\end{abstract}

\begin{abstract}
Abstrak: Tulisan ini bertujuan untuk mendeskripsikan besarnya perhatian yang diberikan al-Qur'ân terhadap permasalahan pemeliharaan lansia. Penulis mengkaji topik ini dengan menggunakan metode tafsir tematis, dengan menghimpun ayat-ayat yang berkaitan erat dengan kata-kata kunci dalam kajian, sesuai dengan metode istiqrâ' (induksi). Di antara kesimpulan pokok dalam tulisan ini, ada begitu banyak kata yang digunakan al-Qur'ân untuk menunjukkan makna lansia seperti al-kibar, 'ajûz, syeikh, arzal al-'umr, wahana al-'azhm, dha'f, dan syaibah. Al-Qurân mengisyaratkan bahwa usia tua adalah masa yang panjang; ada lansia biasa dan lansia akhir, masing-masing memiliki karakteristik yang berbeda. Dalam merawat lansia, beberapa prinsip al-Qur'an harus selalu diperhatikan, di antaranya; memuliakan dan menghormati orang yang lebih tua merupakan salah satu ciri utama masyarakat Islam. Diharapkan melalui prinsip-prinsip al-Qur'ân ini, kepedulian dan penghormatan terhadap orang tua akan semakin baik di kalangan umat Islam, khususnya di Indonesia.
\end{abstract}

Keywords: elderly, Qur'ânic principles, Qur'ânic exegesis 
MIQOT Vol. 45 No. 1 January-June 2021

\section{Introduction}

Human life in the world goes through several stages, beginning with a period of weakness when a person is born as a baby and is completely reliant on those around him, followed by a period of strength as he progressed through adolescence, youth, and adulthood, and finally a period of weakness as he grew older and began to lose one by one of his strengths.

This fact is confirmed by Allâh in Q.S. al-Rûm/30:54; where Allâh asserts that He is the One who created man from weakness, then made after weakness into strength, then made after strength weakness and white hair. Allâh creates what He wills, because He is All-Knowing, All-Powerful.

The elderly are revered in Islam, and they are glorified. In general, the Qur'ân emphasizes children's responsibility to serve their parents, although this requirement gets more forceful and repeated as both parents grow older. If both parents are still living, this is a unique opportunity for a youngster to commit himself to his parents.

One of the âyahs that become an important guide in filial piety to both parents is Q.S. al-Isrâ'/17:23-24, Allâh says: "wa qadhâ rabbuka allâ ta'budû illâ iyyâhhu wa bi al-wâlidaini ihsânâ, immâ yablughanna 'indaka al-kibara aḩaduhumâ au kilâhumâ fa lâ taqul lahumâ uffiw wa lâ tanhar-humâ wa qul lahumâ qaulan karîmâ. wakhfidh lahumâ janâha al-dzulli min al-ra-mati wa qul rabbi irham-humâ kamâ rabbayânî shaghîrâ. It means: "And your Lord has decreed that you worship not except Him, and to parents, good treatment. Whether one or both of them reach old age while with you, say not to them so much as, "uff," and do not repel them but speak to them a noble word. And lower to them the wing of humility out of mercy and say, "My Lord, have mercy upon them as they brought me up when I was small."

According to al-Qurthubî, the âyah above emphasizes the importance of filial piety to both parents in all conditions. Still, the verse above also requires that filial piety to both parents be emphasized even more when both are in an elderly need. ${ }^{1}$

Muslims are obliged to serve their parents with ihssân, especially when they are old. The word $i \underline{h} s a ̂ n$ in the context of caring for the elderly, is a comprehensive obligation that has practical implications, such as showing kindness, honor, compassion, patience, appreciation, ease, tenderness, justice, support, and solidarity. Children are required to take care of their parents when they are weak and unable to support themselves. "Doing good" and "becoming a good Muslim" can be realized by taking care of the elderly with ihssân. ${ }^{2}$

In addition, in many hadiths of the prophet found many signs that show how Islam

\footnotetext{
${ }^{1}$ Abu 'Abdillâh Muhammad al-Qurthubî, Al-Jâmi' Li Ahkkam al-Qur'ân (Beirut: Dâr al-Kutub al-'Ilmiyyah, 1993).

${ }^{2}$ E. MacKinlay, Ageing and Spirituality Across Faiths and Cultures (Philadelphia: PA: Jessica Kingsley Publishers, 2010).
} 
glorifies the elderly, including: Prophet Muhammad PBUH SAW said: amaranî jibrîl an uqaddima al-akâbir. It means: "[Jibril ordered me always to put the elderly first]" (Narrated by al-Albânî).

According to al-Munâwî, among the manifestations of honouring the seniors is prioritizing them to become imams, to eat and drink first. ${ }^{3}$ If in matters of eating and drinking the seniors must be prioritized, what about other things that require their experience and advice, then of course it must also be prioritized.

Prophet Muhammad PBUH also always reminded that it was not from his followers who did not love the juniors among muslims and did not honor and know the rights of the seniors among muslims. (Narrated by Al-Bukhâri).

Al-Bukhâri (d. 870), in his al-Adab al-Mufrad, mentiones three different chapters to the theme of the elderly; notably "bâbal-kabîr" (the Chapter of the Old person), "bâb fadhl al-kabîr" (Chapter of the Virtue of the Old Person), and "bâb yubda'u al-akbar bi alkalâm wa al-suâl" (Chapter of Priority of the Old person as first in both speech and question). ${ }^{4}$ This illustrates how there are so many hadiths of the Prophet that are related to respect for the elderly, and how to realize that respect for them.

Unfortunately, many elderly people nowadays are cared for and neglected. The presence of the elderly in the family is usually viewed as a hardship. The importance of filial devotion to elderly parents as a path to Jannah is sometimes ignored.

This may be observed in the rising number of older people being admitted to nursing facilities. This tendency has previously only grown in non-Muslim nations, particularly in the west, since most Muslim minority families are highly concerned with caring for their own parents at home as a custom..$^{5}$ They believe that placing older Muslim families in nursing facilities will make it harder for them to get faith-related services, however this situation is increasingly common among the majority Muslim community in the Islamic world, particularly in cities.

Several Islamic and general studies on the issue of care for the elderly have been conducted in the past. In 2014, Benaouda Bensaid and Fadila Grine published the paper Old Age and Elderly Care: An Islamic Perspective. ${ }^{6}$ This is a decent book that gives an Islamic perspective on the elderly. It addresses the religious implications of the elderly in Islam, the elderly's place in Islam, the elderly's legal rights in Islam, and other topics.

${ }^{3}$ Zainuddin 'Abd al-Ra'uf al-Munâwi, "Faydh Al-Qadîr Syarh Jami' al-Shaghîr," Al-Maktabah al-Tijariyah Al-Kubrâ 2 (n.d.) 244-45.

${ }^{4}$ Benaouda Bensaid and Fadila Grine, "Old Age and Elderly Care: An Islamic Perspective," Cultura 11, no. 1 (January 2014): 141-63, https://doi.org/10.5840/cultura20141119.

${ }^{5}$ Abir Mohamad Ismail, "Care in Practice: Negotiations Regarding Care for the Elderly in Multigenerational Arab Muslim Families in Denmark," Contemporary Islam, January 2021, https://doi.org/10.1007/s11562-020-00458-8.

6"Old Age Ana Elderly Care An Islamic Perspective," researchgate, 2021. 
Mahjabeen Ahmad, a Muslim scholar in Australia, has published a book Muslim Aged Care: A practical guide for service providers in 2017. ${ }^{7}$ This book is a practical guide for nursing home administrators who want to pay attention to the specific requirements of Muslim old persons who are not like other elderly people. This book was written in response to a need in Australia for nursing homes to give attention to spiritual needs and Islamic instruction, which is critical for the Muslim population there.

This article stems from worries about a number of troubling truths about the current state of the elderly. Unlike the other two studies, this study aims to provide the Qurânic perspective on the significance of caring for the old so that society's paradigm shifts to become more respectful of the elderly who have made significant contributions to society. This work adds to the formulation of Qur'anic concepts for senior care. The Qur'ân must always be utilized as a reference source in this situation, in the sense that the needs of the times must be taken into account while contextualizing the dimensions of the Qur'ân's meaning. ${ }^{8}$

Departing from the above background, there are several academic problems that will be answered in this article, namely: First, what is the Qur'anic perspective on the elderly?, which will then be detailed as follows: 1) what terms are used by the Qur'ân to call the elderly? 2) what are the changes experienced by the elderly in the Qur'anic perspective?, 3) what are the types of elderly according to the Qur'ân? And Second, what are the Qur'ânic principles in caring for the elderly?

\section{Methodology}

This study of the Qur'ânic perspective regarding the care of the elderly is an attempt to express the views of the Qur'ân on social issues that develop in society, which is better known as the interpretation with the socio-cultural (adabîijtimâ'î) style. This is one form of the study of understanding by bringing it closer to the problems that exist in society.

This is a library research project in which the author analyzes reference volumes, particularly comments, journals, and other works related to the topic under consideration. This work may be classed as a theme study of Qur'anic interpretation due to its character.

Because the accuracy of an interpretation can be tracked by evaluating the logical structure and relationship of the âyahs that are in accordance with the object of study, the theme interpretation technique is able to regulate the ideological biases that are imposed

${ }^{7}$ Ahmad, "Https://Meaningfulageing.Org.Au/Wp-Content/Uploads/2017/10/Ahmad2017.Pdf," 2021.

${ }^{8}$ Kusmana, “The Qur'an, Woman and Nationalism In Indonesia: Ulama Perempuan's Moral Movement," Al-Jami'ah: Journal of Islamic Studies 57, no. 1 (June 2019): 83-116, https://doi.org/ 10.14421/ajis.2019.571.83-116. 
in reading the Qurân. As a result, non-Qurânic notions in Qur'ân interpretation can be reduced in this way.

The following are the stages for using the thematic interpretation technique with the appropriate modifications: First, decide on the topic to be presented, which is the Quranic stance on care for the old. Second, gather âyahs that are closely linked to the study's keywords, particularly terms relating to the aged, such as al-kibar, ajûz, syeikh, arzal al-umr, wahn al-azhm, dha'f, and syaibah, as well as their derivatives. Third, carefully analyzing these ayahs in both semantic and semiotic terms, taking into account the âyah's sentence structure as well as features of its asbab nuzul to discover contextually appropriate meaning. Fourth, organize the conversation in a proper framework based on the academic issues raised in this study. Fifth, it includes important hadiths as well as professional interpretations. Sixth, re-examine the overall interpretation of the âyahs concerning the old and seek for current and relevant meanings, then synthesize the Qur'ânic principles in holistic-comprehensive care for the aged. ${ }^{9}$

\section{Results and Discussion}

\section{Definition of Elderly}

The word elderly means someone who has lived a long life, and has seen the signs of aging. In Arabic, the word elderly is usually translated with the word musin. Apart from this word, elderly can also be translated with several other words, such as the word harim, and syaikh.

As for the terminology, there are several definitions of the elderly put forward by different experts, which are influenced by differences in their respective perspectives in focusing on the understanding of the elderly. Some focus on the age of the elderly, some focus on aspects of the physical changes of the elderly, and some focus on various other considerations. ${ }^{10}$

Here are some definitions of the elderly put forward by experts:

1) According to World Health Organization, United Nations and Arab League, "[Elderly is someone who has passed the age of 60 years]."11

2) Abdullah al-Sadhan defines the elderly with "[a condition in which a person experiences a decrease in physical and intellectual abilities, which can be measured, and has an impact on the process of adaptation to his environment.]"12

9 'Abdul Hayyi al-Farmawi, Metode Tafsir Maudhu'i: Suatu Pengantar (Jakarta: RajaGrafindo Persada, 1996).

10 'Abdullâh ibn Nashir ibn 'Abdullâh al-Sadhan, Ri'ayat al-Musinnîn fi al-Islâm, n.d.

${ }^{11}$ Al-Sadhan.

${ }^{12}$ Al-Sadhan. 
MIQOT Vol. 45 No. 1 January-June 2021

3) Kamal Agha defines the elderly as "[a person who has entered old age]" and he defines the nature of old age as "[the biological condition which is the final phase of human development in his life.]"13

4) Ahmad Zaki Badawi defines the elderly as "[a person who is old, where he is no longer able to work as before]."14

The various definitions stated above, although the editorials are quite varied, but the essence is not contradicting each other, in fact one definition complements the other. Variations in the definition above return to the focus of each which is different from the others. However, in author's opinion from the four definitions above, it appears that the first definition which define elderly as someone who has passed the age of 60 years is the most appropriate, because this definition is based on a measured period of time.

Prophet Muhammad PBUH in one of his hadiths also tends to give a time limit to the average age of his ummah, where he said: a'mâru ummatî mâ bayna al-sittîn ilâ al-sab'în, wa aqalluhum man yajûzu dzâlika. It means: "My Ummah is between 60 and 70 years old. And very few of them go through that." (Narrated by Ibn Majah)

\section{Elderly in the Qur'ân}

The word musin as a direct translation of the word elderly is not found in the Qur'ân. However, this does not mean that the Qur'ân does not discuss the elderly because it is necessary to explore further the terms of the Qur'ân, which indicate the meaning of the elderly.

In general, the Qur'ânic terms used to indicate the meaning of elderly in the Qur'ân can be divided into two parts;

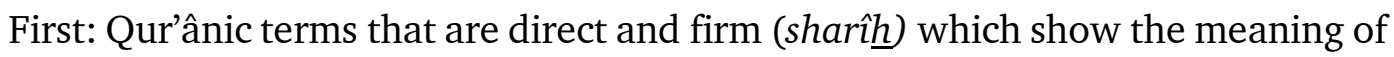
elderly. Among others:

(1) The word "al-kibar", as mentioned in Q.S. al-Hijr/13:54; qâla a basysyartumûnî 'alâ an massaniya al-kibaru fa bimâ tubasysyirûn. In this âyah Allâh explains that Ibrahim was surprised and tried to find a grip so that he could accept the good news by saying "Have you given me good tidings although old age has come upon me? Then of what wonder do you inform?"

${ }^{13}$ Majallah Majma, "Bab ㅂuqûq al-Suyukh wa al-Musinnin wa Wajibatuhum," Al-Fiqh AlIslami OIC 12 (n.d.): 1811.

${ }^{14}$ Zaki Badawi, Mu'jam Musthalahat al-Ri'ayah wa al-Tanmiyah al-Ijtima'iyyah (Cairo: Dâr al-Kitab al-Mishri, 1987). 
Ibn 'Ajîbah in his commentary, explains that the age of Ibrahim when he received the good news of Ishaq's birth had reached one hundred years. ${ }^{15}$

(2) The word "ajûz", as mentioned in Q.S. Hûd/11:72; qâlat yâ wailatâ a alidu wa anâ 'ajûzun wa hâdzâ ba'lî syaikhâ, inna hâdzâ lasyai 'un 'ajîb. This âyah tells how surprised Sarah, Ibrahim's wife, a woman who had entered the menopause period, and her husband was also old, was told to her that she would bear a child in her womb. This news was astonishing and amazing to her.

Ibn Athiyyah al-andalusî explained that the meaning of the word ajûz in the âyah above is an elderly person. Arabs call it the word ajûz or ajûzah. ${ }^{16} \mathrm{Al}$-Farrâ' added that Sarah, Ibrâhîm's wife when she was given the good news regarding her pregnancy, was ninetyeight years old. ${ }^{17}$

(3) The word "syaikh", as mentioned in Q.S. Hûd/11: 72 and Q.S. al-Qashash/28: 23; wa lammâ warada mâ'a madyana wajada 'alaihi ummatan min al-nâsiyasqûna wa wajada min dûnihim umra 'ataini tadzûdân, qâla mâ khathbukumâ, qâlatâ lâ nasqîh hattâyushdira al-ri'â 'u wa abûnâ syaikhun kabîr. This âyah relates that when Moses arrived at the well of Madyan, he found there a crowd of people watering their cattle, and he found beside them two girls holding their cattle. He asked the two why they were standing near people queuing up to fetch water in a crowd of men, when it was more work for a man than for a woman to do. The two girls replied, "We don't water until the shepherds send their cattle. ; and our father is old."

Also in Q.S. Ghâfir âyah 67 Allâh says: huwa alladzî khalaqakum min turâbin tsumma min nuthfatin tsumma min 'alaqatin tsumma yukhrijukum thiflan tsumma litablugû asyuddakum tsumma litakûnû syuyûkhâ, wa minkum may yutawaffâ min qablu wa litablughû ajalam musamma wa la'allakum ta'qilûn. In this âyah Allâh explains that He created man from clay, then from a drop of semen, then from a lump that sticks; then He brought forth man as a child; then He develops people so that they reach maturity, then later they grow old. And among them were those who died before that, so that they reached the appointed time. These are all very amazing things if humans want to think about it."

The word syaikh in the two âyahs above, as conveyed by Muhammad Sayyid Thanthâwî, means that he is old. ${ }^{18}$

${ }^{15}$ Aḥmad Ibn Muhammad al-Mahdi Ibn 'Ajibah, Al-Baḥr al-Madîd (Beirut: Dâr al-Kutub al'Ilmiyyah, 2002).

${ }^{16}$ Abu Muhammad 'Abd al-ㅌaq Ibn 'Athiyyah, Al-Muharrar al-Wajîz, n.d.

${ }^{17}$ Abu Zakariyya Yahya ibn Ziyâd al-Farra', Ma'ânî al-Qur'ân (Beirut: Dâr al-Kutub al'Ilmiyyah, 2002).

${ }^{18}$ Muhammad Sayyid Thanthâwî, Al-Tafsîr al-Wasîth (Cairo: Dâr Nahdhah Mishr, 1997). 
(4) The word "arzal al-'umr", as mentioned in Q.S. al-Nahl/16:70; wallâhu khalaqakum tsumma yatawaffâkum wa minkum may yuraddu ilâ ardzali al-'umuri likai lâ ya'lama ba'da 'ilmin syai 'â, inna Allâha 'alîmun qadîr. This âyah explains that Allâh created man; Then He will also bring people to death. And among mankind there is one who is turned over to the most decrepit old age, so that he knows nothing after he knows it.

According to Imam Muqâtil ibn Sulaimân, arzal al-'umr means elderly. ${ }^{19}$ Meanwhile, Ibn 'Ajîbah stipulates that arzal al-umr when a person has passed the age of seventyfive years. ${ }^{20}$

Second: Qur'ânic terms which are indirect and indecisive (ghairu sharîh ), which also indicate the meaning of elderly. Among others:

(1) The word "Dha'f', as mentioned in Q.S. al-Rûm/30: 54; Allâhu alladzî khalaqakum min dha'fin tsumma ja'ala min ba'di dha'fin quwwatan tsumma ja'ala min ba'diquwwatin dha'fan wa syaibah, yakhluqu mâ yasyâ', wa huwa al-'alîmu al-qadîr. Allâh explains in this âyah that it is He who created humans from weakness, then He made them after being weak to become strong, then He made them after being strong again weak and old until they had white hair.

Wahbah al-Zu-aily in his commentary explains that the purpose of the above âyah is that Allâh makes for a person after a period of strong maturity, a period of weakness in old age comes, which is marked by the appearance of gray hair. ${ }^{21}$

(2) The word "syaibah", as mentioned in Q.S. al-Rûm/30: 54 and Q.S. al-Muzammil/73:17; fa kaifa tattaqûna in kafartum yauma yaj'alu al-wildâna syîbâ. This âyah describes that the Day of Judgment is so terrible, that anyone who witnesses it, if he is a small child he will grow old with white-haired due to the frightening sight.

In the Tafsîr Jalâlayn, the above âyah can be understood in its true meaning, where when conditions are tense, great fear can make a person turn gray. Or it can also be understood metaphorically. ${ }^{22}$

(3) The word "Wahana al-'azhm", as mentioned in Q.S. Maryam/19:4; qâla rabbi innî wahana al-'azhmu minnî wasyta'ala al-ra 'su syaiban wa lam akun bidu'â'ika rabbî syaqiyyâ.

This âyah tells about the Prophet Zakariyya who never gave up hope and prayed to Allâh. In his prayer, Zakariyya describes that his bones have weakened, and his head

\footnotetext{
${ }^{19}$ Muqâtil Ibn Sulaimân al-Balkhi, Tafsîr Muqâtil Ibn Sulaimân (Beirut: Dâr al-Kutub al'Ilmiyyah, 2003).

${ }^{20}$ Ibn 'Ajibah, Al-Bahr al-Madîd.

${ }^{21}$ Wahbah al-Zuhailî, al-Tafsîr al-Munir fi al-'Aqîdah wa al-Syarî́ah wa al-Manhaj (Beirut: Dâr al-Fikr al-Mu'ashir, n.d.). n.d.).

${ }^{22}$ Jalâluddin al-Mahalli and Jalâluddin al-Suyûthi, Tafsîr Al-Jalâlayn (Kairo: Dâr al-Hadits,
} 
is covered with gray hair, he still hopes to have children, because of his belief that Allâh never disappoints him in any of his prayers.

The word wahanal-azhm is an indicator that shows old age, where someone who is old is often faced with health problems, one of which is brittle bones.

From the explanation above, it can be concluded that the Qur'ân tells a lot about the elderly with various terms, each of which has a different accentuation of meaning. ${ }^{23}$ All of these âyahs must be understood holistically-thematically to find a comprehensive perspective of the Qur'ân about the elderly and things related to it.

\section{Changes experienced by the elderly}

The Qur'ân in surah al-Rûm/30: 54 indicates that every human being will experience changes in the process of his life, from being born, to becoming an adult to finally becoming old.

In that âyah, the qurrâ' read the word dha'f with two ways of reading (qirâ'at); some read it dha'fun (with a fathah line on the dhad letter) and other read it with dhu'fun (with a dhammah line on the dhad letter). Linguistically, according to Imam al-Âlûsî, if dha'fun with fathah means weak in terms of mind and maturity of mind, while dhu'fun with dhammah means weak in physical. What is clear, the words dha'fun and dhu'fun are the same as the opposite of the phrase quwwah (strength). ${ }^{24}$

Redaction of Q.S. al-Rûm above is also quite interesting to analyze. Allâh declared "khalaqakum min dha'fin" not with the editor "khalaqakum dhi'afan". According to Sayyid Thanthâwi, this editorial indicates to humans that weakness is the basis from which humans created. This weakness includes the formation of physical, intellectual, emotional, to the human psyche itself. ${ }^{25}$

The changes that will be experienced by each elderly every time they get older include:

(1) Physical Changes

Physical changes in the elderly can be classified into two forms:

First: visible physical changes (external changes), including the shape of the skin starting to dry and wrinkle, changing the hair colour, slow physical response, reduced sensory abilities, etc. ${ }^{26}$

${ }^{23}$ Abu Hilâl al-Askarî, Al-Furûq fì al-Lughah (Beirut: Dâr al-Âfâq al-Jadîdah, 1973).

${ }^{24}$ Syihâbuddîn Mahmûd Ibn 'Abdullâh al-Alûsi, Rûh al-Ma'âni fi Tafsîr al-Qur'ân al-'Azhîm wa al-Sab' al-Matsâni, n. $\overline{\text { d. }}$

${ }^{25}$ Thanthâwî, Al-Tafsîr al-Wasîth.

${ }^{26} \mathrm{Al}-\mathrm{Sadhan}$, Ri'ayat al-Musinnin fi al-Islâm. 
Second: physical changes that are not visible (internal changes), including the form: reduced hearing, blurred vision, diminished sense of smell, and slow movement, and weakened and porous bones. In addition, reduced body resistance, difficulty in breathing, increased potential for fractures and decreased body temperature due to lack of movement. ${ }^{27}$

(2) Intellectual Change

Intellectual changes in the elderly include; weak memory and frequent forgetting, often repeating the exact words, not knowing children and relatives, weak ability to learn new things, and slow thinking skills and slow in making decisions. ${ }^{28}$

(3) Psychological and Emotional changes

Psychological and emotional changes in the elderly can take the form of more sensitive emotions and feelings, get bored quickly, have lots of ideas, complain a lot, boast about the past, full of suspicion and doubt, don't easily trust others, increase attention to religious issues. ${ }^{29}$

(4) Social Change

Social changes in the elderly can take the form of reduced social relations between the elderly and other parties, more focus on staying in touch with old friends, spending more free time alone. ${ }^{30}$

(5) Economic Change

Changes in the elderly's economy take the form of, in general, a person's income decreases because, in general, the elderly have passed retirement. But on the other hand, the greater the expenditure, considering the cost of health care is also getting more significant. Not to mention added to the inflation, which is marked by the increasingly high prices of necessities. ${ }^{31}$

Therefore, it is not surprising that the Prophet, in many of his prayers actually hinted at the importance of Allâh adding a lot of wealth to a person at this age. Prophet Muhammad PBUH said: Allâhumma ij'al awsa'a rizqika 'alayya 'inda kibari sinnî wa inqithâ'i 'umrî. It means: "[O Allâh, make Your sustenance the most extensive for me in my old age, and the end of my life]." (Narrated by at-Thabrâni)

Imam al-Munawi, when explaining the hadith above, explained that an elderly person

${ }^{27}$ Al-Sadhan.

${ }^{28}$ Khalid al-Thahhân, Qadhâya al-Syaikhuhah (al-Kuwait: Dâr al-Qalam, n.d).

29 'Abd al-'Azîz al-Gharib, Al-Mutaqa'idûn: Ba'dh Musykilatihim wa Dawr al-Khidmah alIjtima'iyyah fi Muwajahatiha (Riyadh: Syirkah Najed, n.d).

${ }^{30} \mathrm{Al}-\mathrm{Sadhan}$, Ri'ayat al-Musinnîn fi al-Islâm.

${ }^{31}$ Al-Sadhan. 
is no longer strong in working as he did before, but in fact, his needs sometimes actually increase. $^{32}$

\section{Types of Elderly in the Qur'ân}

Many various terms to denote the meaning of the elderly that used by the Qur'ân indicate that the elderly are not all on the same level. Because according to one definition of the elderly: "those who have entered old age". In Contrast, old age itself measures ranging from past the age of 60 to death. Someone aged from 60 to 70 years is not in the same condition as over seventy-five years old and above. Therefore, in general, the Qur'ân hints at two types of elderly:

First, Ordinary Elderly (al-Musinnûn al-'Âdiyyûn). They are the elderly that Allâh has indicated in the Q.S. al-Rûm/30: 54 with the second word "dha'f'. Yûsuf al-Qardhâwî named this group al-Syaikhukhah al-ÂAdiyyah. ${ }^{33}$

Generally, these ordinary elderly are those whose ages are between 60 to 70 years, as mentioned by the Prophet in the hadith narrated by Ibn Mâjah: a'mâru ummatî mâ bayna al-sittîn ilâ al-sabî̀n, wa aqalluhum man yajûzu dzâlika. It means: "[My Ummah is between 60 and 70 years old. And very few of them go through that]." (Narrated by Ibn Mâjah).

The prophet's words "And very few of them passed through it", according to Al-Mullâ 'Ali Qâri, means very few who passed the age of seventy years until they reached one hundred years or more than that. Anas ibn Malik, one of the companions of the Prophet, was awarded a long life, where he died at the age of one hundred and three years. ${ }^{34}$

Second, Late Elderly (al-Musinnûn al-Muta'akhkhirûn). This late elderly described in Q.S. al-Rûm âyah 54 with the word "Syaibah", or it also mentioned in another âyah with the word "arzal al-'umr". And usually, this late elderly applies to those who are over 70 years old. Where at this age, most of the elderly return to behaving like small children, where they no longer understand various problems with perfect knowledge. ${ }^{35}$ Yûsuf alQardhâwî named this group al-syaikhukhah al-Muta'akhirah. ${ }^{36}$ 'Ali Ibn Abî Thâlib in a narration explains that arzal al-'umr is the age of over seventy-five years. ${ }^{37}$

The Prophet Muhammad PBUH, in many prayers, asked Allâh to avoid this moaning elderly. The Prophet said: Allâhumma innî a'ûdzu bika min al-bukhli wa al-kasal, wa arzali

${ }^{32}$ Zainuddîn 'Abd al-Ra'uf al-Munâwi, Al-Taysir Bi Syarh al-Jâmi' al-Shaghir (Riyadh: Maktabah Imam al-Syâfi'i, n.d.).

${ }^{33}$ Yûsuf Al-Qaradhâwi, "Huquq al-Musinnîn fi al-Islâm," Al-Qaradawi, 2018.

${ }^{34}$ Al-Mulla Ali Qari, Mirqât Al-Mafâtih Syarh Misykat al-Mashâbih, n.d.

${ }^{35}$ Al-Râzi and Fakruddin, Tafsîr Mafâtih al-Ghayb (Beirut: Dâr al-Kutub al-'Ilmiyyah, 2000).

${ }^{36}$ Al-Qaradhâwi, "Huqûq al-Musinnîn fi al-Islâm.".

${ }^{37}$ Jalâluddîn al-Suyuthi, Al-Durr al-Mantsur (Beirut: Dâr al-Fikr, 1993). 
MIQOT Vol. 45 No. 1 January-June 2021

al-umr, wa 'adzab al-qabri, wa fitnat al-dajjal, wa fitnat al-mahyâ wa al-mamât. It means: "O Allâh, I seek refuge in you from being stingy, from lazy, from old age, from the torment of the grave, from the fitna of the Antichrist, and from the fitnah of life and death.." (Narrated by Al-Bukhâri).

\section{Qur'ânic Principles in Caring for the Elderly}

Observing the reviews of the Qur'ân regarding the care of the elderly, it can be concluded that the Qur'ân has laid down the essential principles of caring for the elderly as follows:

(1) Allâh honors man by making him his vicegerent on earth.

Allâh confirms the glory of man in Q.S. al-Isrâ'/17:70, He says; wa laqad karramnâ banî âdama wa-amalnâhum fí al-barri wa al-bahri wa razaqnâhum min al-thayyibâti wa fadhdhalnâhum 'âlâ katsîrin mimman khalaqnâ tafdhîlâ.

The above âyah emphasizes that Allâh has glorified the children of Adam, and Allâh brought them on land and in the sea. In addition, Allâh has also given them good things (thayyibât) and Allâh has also given them preferences from most of what Allâh has created.

Al-Thabarî explained that the form of Allâh glorifies humans by subduing all other creatures so that humans can use them in their lives. ${ }^{38}$

In the hadits of the prophet, it also explained that this human honour is general, both for Muslims and non-Muslims. In a narration, it is mentioned that Jabir Ibn Abdullah RA said, "Once a corpse passed in front of us, then the prophet stood up, we also stood up. Then we said to the Prophet: O Messenger of Allâh, isn't that the body of a Jew? Then the Messenger of Allâh said: idzâ ra'aytum al-janâzata faqûmû. It means: "If you see a corpse, then stand up." (Narrated by Al-Bukhâri).

In another narration mentioned, the prophet Muhammad PBUH stood when the body was being led in front of him, then he was asked; 'Isn't that the body of a Jew?', the Prophet said: alaysat nafsan. It means: "Isn't he also human?" (Narrated by Al-Bukhâri).

The manifestations of how God glorifies humans include:

(a) Allâh chose a man to be His vicegerent on earth, ${ }^{39}$ according to Q.S. al-Baqarah/2: 30; wa idz qâla rabbuka li al-malâ'ikati innîjấilun fi al-ardhi khalîfah, qâlû a taj'alu fihâ mayyufsidu fihâ wa yasfiku al-dimấ, wa nahnnu nusabbih̆u bihamamika wa nuqaddisu lak, qâla innî a'lamu mâ lâ ta'lamûn. This âyah illustrates that when Allâh was going

${ }^{38}$ Abu Ja'far Muhammad ibn Jarîr al-Thabari, Jami' al-Bayân fi Ta'wil Aay al-Qur'ân (Beirut: Mu'assasah al-Risâlah, 2000). Fikr, 2010).

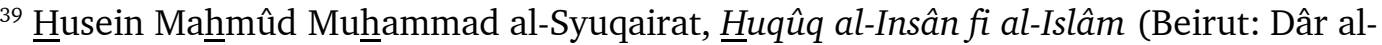


to create Adam, Allâh told the angels that he would make humans a successive authority on earth. Then the angels said, "Will You place upon it one who causes corruption therein and sheds blood, while we exalt You with praise and declare Your perfection?" Allâh answered them firmly, "Indeed, I know that which you do not know."

According to Quraish Shihab, literally, caliph means "Someone who replaces (others) or who came before". ${ }^{40}$ Meanwhile, according to Yudian Wahyudi, the Caliph is a person who is able to manage khilâf (error) and ikhtilâf (difference, diversity, pluralism), so that he has the right to continue, represent and even replace. If you can't afford it, the place is behind (khalf). The word caliph in this context refers to all existing professional positions related to human life..$^{41}$

(b) Allâh made the creation of Adam so special different from the creation of other creatures by perfecting his creation. This is explained in Q.S. Shâd/38: 71-73; idz qâla rabbuka li al-malâ'ikati innî khâliqun basyaran min thîn. fa idzâ sawwaituhû wa nafakhtu fỉhi min rûhîffaqa'û lahû sâjidîn. fa sajada al-malâ'ikatu kulluhum ajma'ûn. This âyah explains that Allâh told the angels that He would create man from clay. Furthermore, after He completed the creation of man, He breathed into it from the spirit of His creation, and at that moment all the angels prostrated themselves in honor of Adam.

Abdul Kodir ${ }^{42}$, as quoted by Asrori Mukhtarom et al. ${ }^{43}$, stated that another reason for the appointment of humans as caliphs was more because humans had the title "ahsan al-taqwîm" in Surah al-Tîn/95: 4 which means the best form, which means that humans are the most beautiful creatures of Allâh. perfect with a set that he has capable of carrying out his caliphate duties. Humans as Khalîfatullâh are not allowed to do anything that is contrary to or contrary to the will of Allâh.

(c) Allâh honours humans with knowledge. ${ }^{44}$ Even the first âyah revealed to the Prophet Muhammad PBUH calls for learning and reading. Pay attention to Q.S. al-'Alaq/96: 1-5; iqra' bismi rabbika alladzî khalaq. Khalaqa al-insâna min 'alaq. iqra ' wa rabbuka al-akram. Alladzî 'allama bi al-qalam. 'allama al-insâna mâ lam ya'lam. These âyahs command people to read in the name of Allâh who created. Because it is Allâh who created man from a clinging substance. Man is commanded to read to know the

${ }^{40}$ Quraish Shihab, Tafsir Al-Mishbah (Jakarta: Lentera Hati, 2002).

${ }^{41}$ Yudian Wahyudi, Khalifah and Khilafah in the Context of the NKRI Based on Pancasila (Jakarta, 2018).

${ }^{42}$ Abdul Kodir, "Konsep Manusia Dalam Al-Qur'an Sebagai Dasar Pengembangan Pendidikan" (UIN Jakarta, 2007).

${ }_{43}^{43}$ Asrori Mukhtarom, Ety Kurniati, and Desri Arwen, "Pendidikan Kewarganegaraan Dalam Perspektif Al-Qur'an'," MIQOT 43, no. 1 (2019): 7-8.

${ }^{44}$ Samiyah al-Manisi, Al-Nida' al-Awwal li Huqû̂q al-Insân fi al-Islam (Kairo: Dâr al-Fikr alArabi, 2005). 
MIQOT Vol. 45 No. 1 January-June 2021

most gracious God, who teaches man by means of a pen. Allâh Teaches people what they don't know."

Ibn Katsir in his commentary, states that the first five âyahs that came down from the Qur'ân are the first rahmah that Allâh gives to His servants, the first favour that Allâh bestows upon them, and in them, there are signs and warnings that human beings created from a lump blood. ${ }^{45}$

The command to read as the first commandment revealed in the Qur'ân shows that reading (qirâ'ah) is a miracle revealed in the Qur'ân throughout the ages. ${ }^{46}$

(d) Allâh has bestowed upon man the mind, the ability to speak, and the ability to distinguish between good and evil. Pay attention to Q.S. al-Rahmân/55:1-4; al-rahmân. 'allama al-qur'ân. Khalaqa al-insân. 'allamahu al-bayân. These âyahs describe that Allâh is The Most Merciful. He taught the Qur'ân to humans. He created man, and also He taught them speech.

(e) Allâh has subdued all His creations in the heavens and the earth to benefit of humans in carrying out their duties as the vicegerent of Allâh. See Q.S. al-Jâtsiyah/ 45:13; wa sakhkhara lakum mâ fî al-samâwâti wa mâ fí al-ardhi jamî‘an minhu, inna fí dzâlika la 'âyâtin liqaumin yatafakkarûn. It means: "And He has subjected to you whatever is in the heavens and whatever is on the earth - all from Him. Indeed in that are signs for a people who give thought."

(f) Allâh cares for humans. Pay attention to Q.S. al-Thâriq/86: 4; in kullu nafsin lammâ 'alaihâ hâfizh. It means: "There is no soul but has a protector over it."

and Q.S. al-Râ'd/13: 11: lahû mu'aqqibâtun min bayni yadaihi wa min khalfihî yahfazhûnahû min amri Allâh, inna Allâha lâ yughayyiru mâ biqaumin-attâyughayyirû mâ bi'anfusihim, wa idzâ arâda Allâhu biqaumin sû'an fa lâ maradda lah, wa mâ lahum min dûnihîmin wâl. This âyah explains that for each person there is an angel who follows behind him whose duty is to protect him by Allâh's decree. Allâh asserts that He will not change the condition of a people until they change what is in themselves. God's will is absolute. If Allâh wills pain for a people, then no one can refuse it. Because Allâh is the only protector.

(g) Allâh has bestowed upon man a trust (Amânah) and gave him freedom of choice. This confirmed in Q.S. al-Ahzâb/33:72; innâ 'aradhnâ al-amânata 'alâ al-samâwâti wa al-ardhi wa al-jibâli fa abaina an yahmilnahâ wa asyfaqnâ minhâ wa hamalaha al-insân, innahû kâna zhalûman jahûlâ. This âyah describes that Allâh has given

${ }^{45}$ Al-Alûsi, Rûh al-Ma'âni fi Tafsîr al-Qur'ân al-'Azhîm wa al-Sab' al-Matsâni.

${ }^{46}$ M. Djidin and Sahiron Syamsuddin, "Indonesian Interpretation Of The Qur'an On Khilâfah The Case of Quraish Shihab and Yudian Wahyudi on Qur'an 2: 30-38," Al-Jâmi'ah/: Journal of Islamic Studies 57, no. 1 (2019): 155. 
the trust to the heavens and the earth and the mountains, but they are reluctant to carry it and are afraid of it; When Allâh offers the trust to man, he accepts the trust and tries to bear it. But because of ignoring this trust, some people become unjust and ignorant."

A person's freedom to do something does not mean it is absolute, because he is limited by existing rules. The Western world, which tends to spread this fundamental freedom, is starting to reap its negative effects now. ${ }^{47}$

(h) Allâh sent Prophets and Messengers from among the human race to convey guidance to mankind. See Q.S. al-Baqarah/2: 151; kamâ arsalnâ fikum rasûlan minkum yatlû 'alaikum âyâtinâ wa yuzakkîkum wa yu'allimukum al-kitâba wa al-hikikmata wa yu'allimukum mâ lam takûnû ta'lamûn. This âyah explains that the main task of a messenger sent by Allâh to mankind is to recite the âyahs of Allâh to mankind, and purify humans, and teach them the Book and Wisdom. Moreover, a messenger also teaches people what they do not know.

and Q.S. al-Hadîd/57:25; laqad arsalnâ rusulanâ bi al-bayyinâti wa anzalnâ ma'ahum al-kitâba wa al-mîzâna liyaqûma an-nâsu bi al-qisth ... This âyah explains that Allâh has sent His messengers with clear evidences and He has sent down with them the Holy Book and balance so that people can guard against the injustice of their affairs.

And there are many other forms of how Allâh glorifies humans, which are the basis of human rights in the Islamic perspective, which is reflected in many âyahs of the Qur'ân. ${ }^{48}$

(2) Allâh created man from one soul.

This is in accordance with Q.S. al-Nisâ'/4: 1;yâ ayyuha al-nâsu ittaqû rabbakum alladzî khalaqakum min nafsin wâhidatin wa khalaqa minhâ zaujahâ wa batstsa min-humâ rijâlan katsîran wa nisâ'â, wattaqu Allâha alladzî tasâ'alûna bihî wa al-arhâam, inna Allâha kâna 'alaikum raqîbâ. In this âyah, Allâh calls upon mankind and commands them to fear Allâh, for it is He Who created man from one soul and created from it its mate, and dispersed from both of them many men and women. Therefore, humans must put their trust in Allâh in all their affairs.

Regarding the above âyah, al-Thabarî commented that Allâh describes Himself as Who created all humankind from one soul, to introduce His servants to how the creation of one soul began, and to remind them that they are all children of one soul. one father and mother, some of them are part of the other. Some of their obligations to others are

${ }^{47}$ Elviandri and Dkk, "The Formulation of Welfare State: The Perspective of Maqâsid AlSharı̂a," Indonesian Journal of Islam and Muslim Societies 8, no. 1 (2018): 117-46, https:// doi.org/10.18326/ijims.v8i1.

${ }^{48}$ Yahya Ibn Muhammad Hasan Zamzami, Al-Manhaj al-Akhlâqi wa $\underline{H} u q u \hat{q} q$ al-Insân fi alQur'ân al-Karîm, n.d. 
MIQOT Vol. 45 No. 1 January-June 2021

like brother's obligations to other brothers, because their lineage united to one father and mother. ${ }^{49}$

Al-Zu-ailî also stated that Allâh made from all the descendants of Adam there are kindship ties built on the unity of the womb, blood relations, and kinship, so that they love each other and help each other. ${ }^{50}$

The Qur'ân states that Allâh has exalted the status and dignity of all the children of Adam, because they were all created from one soul. The glory of this position should not be tainted by the attitude of humans who humble themselves, ${ }^{51}$ including by degrading other than themselves.

(3) Allâh commands every human being to be devoted to his parents, as a manifestation of concern and care for the elderly.

Pay attention to the word of Allâh in Q.S. al-Nisâ'/4: 36; wa u budû Allâha wa lâ tusyrikû bihî syai'an wa bi al-wâlidaini ihnsâna wa bi dzil-qurbâ wa al-yatâmâ wa al-masâkîni wa al-jâri dzil-qurbâ wa al-jâri al-junubi wa al-shâhibi bi al-jambi wa ibni al-sabîli wa mâ malakat aymânukum, inna Allâha lâ yuhibbu man kâna mukhtâlan fakhûrâ. In this âyah, Allâh commands people to worship Him and not associate Him with anything. Allâh also commands people to do good to parents and relatives, orphans, the needy, the near neighbor, the neighbor farther away, the companion at your side, the traveler, and those whom your right hands possess relatives, orphans, poor people, close neighbors, distant neighbors, companions by your side, travelers, and people who are your rights. Allâh also explains that He does not like those who are self-deluding and boastful.

Also in Q.S. al-Isrâ'/17:23-24 Allâh says; wa qadhâ rabbuka allâ ta 'budû illâ iyyâhu wa bi al-wâlidayni ihssânâ, immâyablughanna indaka al-kibara ahaduhumâ au kilâhumâ fa lâ taqul lahumâ uffin wa lâ tan-har-humâ wa qul lahumâ qaulan karîmâ. wakhfidh lahumâ janâha al-dzulli min al-rậmati wa qul rabbi ir-h̆am-humâ kamâ rabbayânî shaghîrâ. In this âyah Allâh explains that He has decreed that humans should not worship other than Him, and that humans must treat their parents well. Respect and being kind to parents is increasingly emphasized for children when parents, both or one of them, reach old age. Allâh forbids humans to say words that hurt both of them, even if they only say the word "uff," and Allâh also forbids children from expelling their parents. The child must speak to both of them with noble words. No matter how high the position and position of the child, he must be humble to his parents, caring for them with compassion.

${ }^{49}$ Al-Thabari, Jami' al-Bayân fi Ta'wil Aay al-Qur'ân.

${ }^{50}$ Al-Zuhailî, al-Tafsîr al-Munîr fi al-'Aqîdah wa al-Syarî‘ah wa al-Manhaj.

51 Taiwo T. Ambali, "Social and Economic Foundations of Community Education for Peace in Islam," International Journal of Islamic Thought 11, no. 1 (May 2017): 52-58, https:// doi.org/10.24035/ijit.11.2017.006. 
In addition, children are also required to always pray for them by saying: "My Lord, have mercy upon them as they brought me up when I was small.

Al-Jazâirî when commenting on the âyah "but speak to them a noble word" explains "[and say to both words that are noble, kinder, more gentle, showing respect and affection for both]." 52

If the âyah above specifically commands to be devoted to both parents when both are elderly, then the âyah also implies the urgency of paying attention to the elderly group in general.

Gentle words are related to the choice of words and the redaction of the words conveyed and related to the intonation of the voice that is not too high but can also be heard well because intonation is too high also hurt other people especially the elderly. ${ }^{53}$

There are so many hadiths of the Prophet that show the urgency of serving both parents, especially when both of them have entered old age, including:

(a) The Messenger of Allâh PBUH said in a hadith narrated from Abu Usaid Malik bin Rabî'ah al-Sa'îdi, he said: baynâ nahnu 'inda Rasulillâh sallalâhu 'alaihi wa sallam idzâ jâ'ahu rajulun min Bani salamah fa qâla Yâ Rasulallâh hal baqiya min birri abawayya syaiun abarruhumâ ba'da mautihimâ, qâla na'am, al-shalâtu 'alaihimâ, wa al-istighfâru lahumâ, wa infâdzu 'ahdihimâ min ba'di himâ wa shilaturrahimi allatî lâ tûshal illâ bihimâ wa ikrâm shadîqihimâ. It means: "One time we were with the Prophet PBUH. When someone from Banu Salimah came, he said, "O Messenger of Allâh, is there any form of filial piety to my parents when they have died?" The Prophet PBUH replied, "Yes (there is still a form of filial piety to both of them.). The form is praying for both of them, asking forgiveness for both of them, fulfilling their promise after death, establishing a friendship (kinship) relationship with the families of both parents who never existed and glorifying their close friends.." (Narrated by Abû Dâwûd and Ibn Mâjah. This hadith is authenticated by Ibn Hibbân).

(b) The messanger of Allâh PBUH said: 'an Abi Hurairata anna Rasulallâhi sallalâhu 'alaihi wa sallama raqiya al-minbara faqâla: Âmîn, Âmîn, Âmîn, faqûla lahû: Yâ Rasulallâhi, Mâ kunta tashna' hâdzâ? Faqâla: Qâla lî Jibrîl: Arghamallâhu Anfa abdin au ba'uda dakhala Ramadhân fa lam yughfar lahû, faqultu: Âmîn, tsumma qâla: raghima anfu abdin au ba'uda adraka wâlidayhî au ahadahuma lam yudkhilâhu al-jannah, faqultu: Âmîn, tsumma qâla: raghima anfu abdin au ba'uda zukirta 'indahu fa lam yushallî 'alaika, faqultu: Âmîn. It means: "From Abu Hurairah ra. Indeed the Messenger of Allâh (PBUH) went up the pulpit and said: Amen, amen, amen (may Allâh accept). Someone asked him: "O Messenger of Allâh, what are you doing?" He replied: "The angel Gabriel said to me: May Allâh harm a servant or keep him away, one who

${ }^{52}$ Abu Bakr al-Jazâiri, "Aysar al-Tafâsîr" 2 (n.d.): 341. 
gets the month of Ramadan, but he is not forgiven. So I said: "Amen." Then Gabriel said: "Woe to a servant or kept away, the one who gets both his parents or one of the two, but that does not enter into heaven." So I said, "Amen". Then Gabriel said again: "May Allâh harm a servant or keep him away, my name is mentioned, but he does not pray to you." So I said "Amen". (Narrated by Ibnu Huzaimah, al-Tirmizî, Ahmad, and Ibn Mâjah)

(c) The Messenger of Allâh PBUH said in a hadith narrated from 'Abdullâh Ibn Mas'ûd that he said: sa'altu Rasulallâhi sallalâhu 'alaihi wa sallama, qultu: yâ Rasulallâhi ayyu al-'amali afdhalu? Qâla: al-shalâtu 'alâ mîqâtihâ, qultu: tsumma ayyu? Qâla: tsumma birru al-wâlidayni, qultu: tsumma ayyu? Qâla: al-jihâdu fì sabilillâh. Fa sakattu 'an Rasulillâh sallalâhu 'alaihi wa sallama wa lau istazadtuhû lazâdanî. It means: I asked the Messenger of Allâh PBUH: O Messenger of Allâh, what is the most honorable deed? He replied: pray on time. I asked again: Then what, O Messenger of Allâh? He replied: Then be filial to both parents. I asked again: Then what, O Messenger of Allâh? He replied: Then jihad in the way of Allâh. Then I kept silent (don't ask) the Messenger of Allâh again, and if I asked again, surely he would answer. (Narrated by al-Bukhâri and Muslim).

(d) The messanger of Allâh PBUH said: man ahabba an yumadda lahû fí 'umrihi wa yuzâdu lahû fî rizqihî fa liyabirra wâlidayhi wa liyashil rahimahû. It means: "Whoever wants to prolong his life and increase his sustenance, then he should be devoted to his parents and continue the relationship." (Narrated by al-Baihaqi).

(4) Islamic society is a society that loves and helps each other.

Pay attention to the word of Allâh in Q.S al-Fat-/48: 29; muhammadun rasûlullâh, wa alladzîna ma'ahû asyiddâ'u 'ala al-kuffâri ruhamâ'u bainahum. This âyah describes the prophet Muhammad as the messenger of Allâh and explains the characteristics of the followers of the prophet, namely forceful against the disbelievers, merciful among themselves..."

Sayyid Thantâwi stated "[The followers of the Prophet are not absolute strict people, nor are they absolutely loving. Their harsh attitude is directed towards their enemies, and their affection is directed towards their fellow brothers and sisters as well as faith.]"54 One of the important lessons from the Qur'ân according to Sehat Sultoni Dalimunte ${ }^{55}$, there is no concept of hating humans in the Qur'ân. There is the concept of assyiddâ'

${ }^{53} \mathrm{Md}$. Nazmul Hasan and Md. Mozammel Hoque, "Influence of Sound from the Words of Human Beingwith Special Reference to al-Quran (31:19), "International Journal of Islamic Thought 7 (2015): 72.

${ }^{54}$ Thanthâwî, Al-Tafsir Al-Wasîth.

${ }^{55}$ Sehat Sultoni Dalimunthe, "Perspektif Al-Qur'an Tentang Pendidikan Akhlak," MIQOT 39, no. 1 (2015): 155. 
(firm: hard) against the disbelievers and it does not mean hate. ${ }^{56}$ There is also the concept of war (qâtilû), not the concept of hate. Against Satan, Allâh only says "lâ tattabi'û: do not follow"57

Allâh also says in Q.S. Al-Balad/90: 17; tsumma kâna min alladzîna âmanû wa tawâshau bi al-shabri wa tawâshau bi al-marhamah. This âyah describes the characteristics of people who believe that they advise each other to be patient and advise each other to be merciful to one another.

al-Thabarî explains that among the characteristics of believers (al-Mu'minûn), they advise each other to be patient with what Allâh has decreed for them, and instruct each other to love one another. ${ }^{58}$

It is undeniable that the notions of secularism and postmodernism in the era of globalization have more or less a negative impact on diminishing the values of compassion in Islamic society. This is what needs to be anticipated so that every Muslim will increasingly lose his identity. ${ }^{59}$ And this is one of the reasons for the need for a progressive interpretation of the concept of ummah. ${ }^{60}$

In the hadits of the Prophet, found a lot of emphasis from the Prophet about the urgency of loving and helping each other among fellow members of the Muslim community, including:

(a) The messanger of Allâh PBUH said: 'an Nu'man ibn Basyîr innahu qâla: qâla Rasulullâhi: tarâ al-mukminîna fi tarâhumihim wa tawâddihim wa ta'âthufihim kamatsali aljasadi, idzâ isytakâ 'udhwun tadâ'â lahu sâiru jasadihî bi al-sahari wa al-ȟummâ. It means: "From al-Nu'man ibn Bashir ra. Where he said: "The Messenger of Allâh PBUH said: "You see the believers in compassion, loving-kindness and gentleness in their association are like one body, where if one member complains of pain then the other members can feel it without being able to sleep and fever" (Narrated by AlBukhâri).

(b) The messenger of Allâh PBUH said: 'an abîhamzata Anas ibn Mâlik khâdimi Rasulillâh 'ani al-nabî qâla: lâyu'minu a-adukum -attâ yuhibba li akhîhî mâ yuhibbu li nafsihî. It means: "From Abu Hamzah Anas bin Malik, helper of the Prophet Muhammad,

${ }^{56}$ Q.S. Al-Fath/48: 29., n.d.

57 “'Satan Is a Real Enemy “'Aduwun Mubîn” Is Mentioned Seven Times in the Qur'an and Three Times Begins with the Sentence, 'lâ Tattabi"û: Do Not Follow".,' Q.S. Al-Baqarah/2: 168, 208, Q.S. Al-An'âm/6: 142, Q.S. Al-A'râf/7: 22, Q.S. Yûsuf/12: 5, Dan Q.S. Yâs," n.d.

${ }^{58}$ Al-Thabari. Jami' al-Bayân fi Ta'wil Aay al-Qur'ân.

${ }^{59}$ Zakaria Stapa, "Malay-Muslim Identity in the Era of Globalization," International Journal of Islamic Thought 10, no. 1 (December 2016): 55-67, https://doi.org/10.24035/ijit.10.2016.006.

${ }^{60}$ Hasnan Bachtiar, "Towards a Progressiveinterpretation of Ummah," Indonesian Journal of Islam and Muslim Societies 8, no. 1 (2018): 122, https://doi.org/10.18326/ijims.v8i1. 
from the Prophet PBUH he said, "None of you is perfect in faith, until he loves for his brother what he loves for himself." (Narrated by at-Tirmidzi)

(c) The messanger of Allâh PBUH said: 'an Jarir ibn 'Abdillâh qâla: qâla Rasûlullâh sallallâhu 'alaihi wa sallam: man lâ yarham lâ yurham. It means: "From Jarir ibn 'Abdillâh said that the Messenger of Allâh PBUH once said, "Those who do not love humans will not be loved by Allâh 'Azzâ wa Jallâ!” (Narrated by Muslim)

(d) The messenger of Allâh PBUH said: al-râhimûn yarhamuhum al-raḥmân, irhamâ man fíal-ardhi yarhamukum man fí al-samâit. It means: "A merciful person will be loved by the Most Merciful God. You have to love those on earth, then you will be loved by those above the sky." (Narrated by al-Tirmidzi, Abu Dawûd, and A-mad).

According to Ibn Hajar, the call "You have to love those on earth" includes the believer, the disbeliever, the possessed and the non-possessed animal. Included in the form of affection is the promise to give food and drink, lighten the burden carried, and not to abuse by hitting. ${ }^{61}$

According to al-Mubârakfûri, the meaning of "you will be loved by those above the sky" can be understood to be loved by Allâh as the most merciful, or it may also be understood to be loved by angels, because they always pray for the good of those who believe.. ${ }^{62}$

(5) Elderly people go through life in a phase of weakness

The weakness of the elderly takes many forms, as previously explained. Therefore, it is obligatory for fellow believers to love the elderly because of the weaknesses they experience.

(6) The elderly who believe for them their position with Allâh, and Allâh does not increase for them their age except for good for them

The basis for this principle is found in many hadiths of the prophet, including:

(a) The messanger of Allâh PBUH said: 'an Abi Hurairah radhiyallâhu 'anhu 'an Rasulillâh sallalâhu alaihi wa sallama qâla: lâ yatamannâ ahadukum al-mawta, wa lâ yad'û bihi min qabli an ya'tiyahu, innahû idzâ mâta ahadukum inqatha'a 'amaluhû wa innahû lâ yazîdu al-mukmina 'umrahu illâ khairâ. It means: "From Abu Hurairah RA, from the Prophet Muhammad PBUH he said: Do not let any of you hope to die, and do not pray for death before it comes. Verily, when one of you dies, his deeds are cut off, and indeed, the believer does not age except for good." (Narrated by Muslim).

(b) The messanger of Allâh PBUH said: khiyârukum athwalukum 'â'mâran idzâ saddadû. It means: "The best among you is the one who has the longest life if he acts right." (Narrated by Abû Ya'lâ al-Maushilî).

${ }^{61}$ Ibn Hajar al-Asqalâni, Fath al-Bâri Syarh Shahîh $\underline{h}$ al-Bukhâri, ed. Ahmad ibn 'Ali al-Syâfíi (Beirut: Dâr al-Ma'rifah, n.d.).

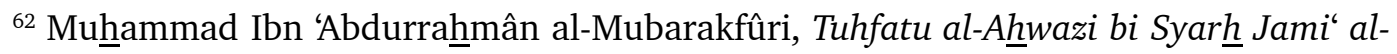
Tirmidzi (Beirut: Dâr al-Kutub al-'Ilmiyyah, n.d.). 
(c) The mesanger of Allâh PBUH said: khiyârukum athwalukum 'â'mâran wa a-sanukum 'â'mâlan. It means: "The best among you are those who live the longest and do the best." (Narrated by Abû Ya'lâ al-Maushilî).

(7) Glorifying and respecting the elderly is one of the main characteristics of Islamic society One of the glorification and respect for the elderly is reflected in how one's manners are in communicating and talking to the elderly. According to al-Mâwardî, as quoted by Mohd Nasir ${ }^{63}$, there are four things that are important to consider in speaking so that someone is considered civilized in their communication, especially for the elderly, namely; (1) The speech should have a purpose, (2) The conversation should pay attention to the conditions and situations of the place and time, (3) The conversation should be in accordance with the needs, and (4) The conversation should choose the best editorial and expression. ${ }^{64}$

There are many evidences, especially from the hadith of the prophet and the atsar of the Companions and the righteous which show that glorifying the elderly is one of the forms of glorifying Allâh and deeds that bring us closer to Allâh. The history includes:

(a) The messanger of Allâh PBUH said: inna min ijlâlillâh ikrâm dzî al-syaibah al-muslim. It means: "Indeed, among the forms of glorifying Allâh, glorifying the elderly Muslims." (Narrated by al-Bukhârî in al-Adab al-Mufrad).

(b) Anas RA narrated that there was an elderly person who wanted to meet the Prophet in his assembly, but the people who were present were slow to provide a way and a place for the elderly to sit and talk near the Prophet, then the Messenger of Allâh said: laysa minnâ man lam yarham shaghîranâ wa lam yuwaqqir kabîranâ. It means: "Not from our group who doesn't love the young and doesn't respect the old." (Narrated by al-Tirmidzi).

(c) Anas RA narrates, when the Prophet liberated the city of Mecca and he entered the Masjid al-Haram, Abu Bakr came to the Prophet with his father who he led, to introduce him to the Prophet, in the hope that his father would convert to Islam. When the Prophet PBUH saw Abu Bakar's father, the Messenger of Allâh said: "Why don't you let this old man stay in his house, and I will come to visit him?" Abu Bakr then said: "O Messenger of Allâh, it is he who should come to you rather than you coming to him. Then, the prophet sat Abu Bakar's father near him, the Prophet honored him, then rubbed his chest while inviting him to convert to Islam, until finally the old man became a Muslim. (Narrated by Ibn Hibbân).

(d) From Ibn 'Umar r.a., the messanger of Allâh PBUH said: amaranî jibrîl 'an uqaddim

${ }^{63}$ Mohd Nasir, "Tarbiyah al-Âdâb 'inda al-'Ulamâ' al-Qadîmah: Tahlîl Afkâr al-Mâwardî fî al-Tarbiyah al-Akhlâqiyah," MIQOT/ : Jurnal Ilmu-Ilmu Keislaman 39, no. 1 (2015), 176.

${ }^{64}$ Al-Mâwardî, Âdab Ad-Dunya wa al-Dîn (Beirut: Dâr al-Kutub al-'Ilmiyyah, 2003). 
al-akâbira. It means: "Jibril ordered me to always put the elderly first" (Narrated by al-Albânî)

(e) The Prophet's message to the Mujahideen troops before being released to war: ughzû bismillâh wa qâtilû man kafara billâhi, wa lâ taghullû, wa lâ tumassilû, wa lâ taqtulû walîdan wa lâ syaikhan kabîran. It means: "Attack them in the name of Allâh, and fight those who disbelieve in Allâh, do not ghalul, do not mutilate, do not kill children and the elderly." (Narrated by al-Haitsami).

(f) Stories of how friends and righteous people glorify the elderly:

a. Imam al-Suyûthî in his book Jâmi' al-Ahâdits narrates the story of an elderly Jew who at the end of his life during the reign of 'Umar Ibn al-Khattâb begged on the streets. 'Umar who saw it, stated that it was a sin for him to quote jizya from him in his youth, but ignored his fate in old age. Umar also determined the rights of the Jewish elderly from baytulmâl. ${ }^{65}$

b. Caliph 'Umar Ibn 'Abd al-'Azîz, once wanted to sleep with his wife, but he could not sleep. Then his wife asked: why, O Amîrul mu'minîn? Umar Ibn 'Azîz replied: "How can I sleep soundly, when on my shoulders there is a mandate to take care of the people of the Prophet Muhammad. There are among them the poor, the weak, the elderly. Finally, the wife of Fathima bint 'Abd al-Malik cried with her husband thinking about the fate of his people. ${ }^{66}$

c. 'Umar Ibn 'Abd al-'Azîz greatly venerated the elderly, especially the elderly scholars. Among those whom 'Umar asked for advice the most was Imam al-Hasan alBashrî. Once Umar asked for advice to al-Hasan al-Bashrî, and he then replied: "O Amîrul mu'minîn, be like a brother to Muslims, as a son to the elderly, like a father to the youth and children, punish each of them. According to the degree of error by paying attention to their physical strength, and do not strike one whip in a state of peak anger, so that you go to hell because of it." ${ }^{\prime 67}$

d. 'Umar Ibn 'Abd al-Azîz also once sent a letter to his governor in charge of the Arabian Peninsula, Maymun ibn Mihran asking that he be released from the task of quoting the kharaj and deciding the law among humans considering his advanced age. 'Umar Ibn 'Abd al-Azîz replied to his request by saying carry out your duties according to the limits of your ability. If there is a problem that arises beyond 386.

${ }^{65}$ Jalâluddîn al-Suyuthi, Jami' al-Ahadits, "Bab Musnad 'Umar Ibn al-Khaththab” 28 (n.d.),

66 'Aidh al-Qarnî, Mujtama' al-Matsal (Beirut: Dâr ibn Hazm, 2000).

${ }^{67}$ Iffat Wishâl Hamzah, Sîrah 'Umar Ibn 'Abd al-'Aziz Khamis al-Khulafâ' al-Rasyidîn (Beirut: Dâr ibn Hazm, 1998). 
your ability to solve it, let me know. Because if humans quickly give up on all the difficulties they face, then there will be no religious or world affairs. ${ }^{68}$

From the beauty of the teachings of the Qur'ân on the care of the elderly, it can be concluded that it is the government should prepare nursing homes to accommodate the elderly who need a place to take shelter. And this obligation is in line with siyâsat syar'iyyah and benefit. However, it is a form of disobedience when a child allows his elderly parents to be cared for in a nursing home when he can take advantage of the moment to show his devotion to his parents.

\section{Conclusion}

The elderly is given special attention in the Qur'an. That was represented not just in the numerous terms employed by the Qur'ân to describe old age, such as al-kibar, 'ajûz, syeikh, arzal al-'umr, wahana al-'azhm, dha'f, and syaibah. According to the Qur'ân, old age is a long span of time; there are ordinary elderly and late elderly people, each with their own set of traits. Several Qur'ânic principles should always be considered when caring for the elderly, including: Allâh honors humans by making them His vicegerents on earth; Allâh creates humans from one soul; Allâh commands every human being to be devoted to his parents as a manifestation of concern and care for the elderly; and the elderly go through life alone. It is anticipated that through following these Qur'anic principles, the Muslim society, particularly in Indonesia, will show more compassion and respect for the elderly.

\section{References}

Al-Alûsi, Syihâbuddîn Mahmûd Ibn 'Abdullâh. Rûh al-Ma'âni Fỉ Tafsîr al-Qur'ân al-'Azhîm wa al-Sab' al-Matsâni, n.d.

Al-Askarî, Abu Hilâl. Al-Furûq Fî al-Lughah. Beirut: Dâr al-Âfâq al-Jadîdah, 1973.

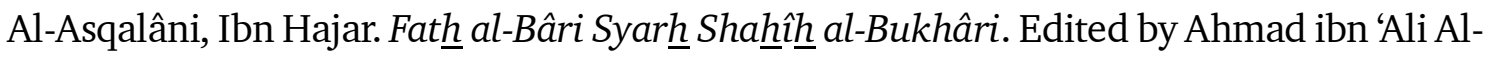
Syâfi'i. Beirut: Dâr al-Ma'rifah, n. $\bar{d}$.

Al-Balkhi, Muqâtil Ibn Sulaimân. Tafsîr Muqâtil Ibn Sulaimân. Beirut: Dâr al-Kutub al'Ilmiyyah, 2003.

Al-Farmawi, 'Abd al-Hayyi. Metode Tafsir Maudhu'i: Suatu Pengantar. Jakarta: RajaGrafindo Persada, 1996.

Al-Farra', Abu Zakariyya' Yahya ibn Ziyâd. Ma'ânî al-Qur'ân. Beirut: Dâr al-Kutub al-'Ilmiyyah, 2002.

${ }^{68}$ 'Abd al-Sattar al-Syeikh, 'Umar Ibn 'Abd al-'Aziz Khamis al-Khulafâ' al-Râsyidîn (Damaskus: Dâr al-Qalam, 1992). 
MIQOT Vol. 45 No. 1 January-June 2021

Al-Gharib, 'Abd al-'Azîz.Al-Mutaqa'idûn: Ba'dh Musykilatihim wa Dawral-Khidmah al-Ijtimaìyyah fi Muwajahatiha. Riyadh: Syirkah Najed, n.d.

Al-Jazâiri, Abu Bakr. "Aysar Al-Tafâsîr" 2 (n.d.): 341.

Al-Mahalli, Jalâluddîn, and Jalâluddin al-Suyûthi. Tafsîr al-Jalâlayn. Kairo: Dâr al-ㅂadîts, n.d.

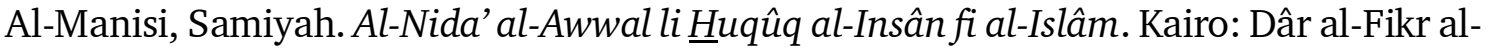
'Arabi, 2005.

Al-Mâwardi. Âdab al-Dunya wa al-Dîn. Beirut: Dâr al-Kutub al-Ilmiyyah, 2003.

Al-Mubarakfûri, Muhammad Ibn 'Abdurrahmmân. Tuhfatu al-Ahwazi Bi Syarh Jami' alTirmidzi. Beirut: Dâr al-Kutub al-'Ilmiyyah, n.d.

Al-Munâwi, Zainuddîn 'Abd al-Ra'uf.Al-Taysir bi Syarh al-Jâmi' al-Shaghîr. Riyadh: Maktabah Imam al-Syâfi'i, n.d.

Al-Munâwi, Zainuddîn 'Abd al-Ra'uf. "Faydh al-Qadîr Syarh Jami' al-Shaghîr." Al-Maktabah al-Tijariyah al-Kubrâ 2 (n.d.): 244-45.

Al-Qaradhâwi, Yûsuf. "Huquuq al-Musinnîn fi al-Islâm.” Al-Qaradawi, 2018.

Al-Qarni, 'Aidh. Mujtama' al-Matsal. Beirut: Dâr Ibn Hazm, 2000.

Al-Qurthubî, Abu 'Abdillâh Muhammad. Al-Jâmi' li Ahkkam al-Qur'ân. Beirut: Dâr al-Kutub al-'Ilmiyyah, 1993.

Al-Sadhan, 'Abdullâh ibn Nashir ibn 'Abdullâh. Ri'ayat al-Musinnin fi al-Islâm, n.d.

Al-Suyûthi, Jalâluddin. Al-Durr al-Mantsur fi al-Tafsîr bi al-Ma'tsur. Beirut: Dâr al-Fikr, 1993.

Al-Suyûthi, Jalâluddin. "Jami' al-Ahadits, Bab Musnad 'Umar Ibn Al-Khaththab” 28 (n.d.): 386.

Al-Syeikh, 'Abd al-Sattar. 'Umar Ibn 'Abd al-'Azîz Khamis al-Khulafâ' al-Râsyidîn. Damaskus: Dâr al-Qalam, 1992.

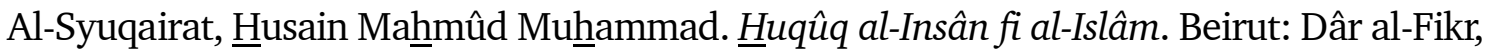
2010.

Al-Thabari, Abu Ja'far Muhammad ibn Jarîr. Jami' al-Bayân fi Ta'wil Aay al-Qur'ân. Beirut: Mu'assasah al-Risâlah, 2000.

Al-Thahhân, Khalid. Qadhâya al-Syaikhuhah. al-Kuwait: Dâr al-Qalam, n.d.

Al-Zuhailî, Wahbah. Al-Tafsîr al-Munir fi al-'Aqîdah wa al-Syarî‘ah wa al-Manhaj. Beirut: Dâr al-Fikr al-Mu'ashir, n.d.

Bachtiar, Hasnan. "Towards a Progressive Interpretation of Ummah." Indonesian Journal of Islam and Muslim Societies 8, no. 1 (2018): 122. https://doi.org/10.18326/ijims.v8i1.

Badawi, Zaki. Mu'jam Musthalahat al-Ri'ayah wa al-Tanmiyah al-Ijtima'iyyah. Kairo: Dâr al-Kitab al-Mishri, 1987.

Bensaid, Benaouda, and Fadila Grine. "Old Age and Elderly Care: An Islamic Perspective." Cultura 11, no. 1 (January 2014): 141-63. https://doi.org/10.5840/cultura20141119. 
Dalimunthe, Sehat Sultoni. "Perspektif Al-Qur'an Tentang Pendidikan Akhlak." MIQOT 39, no. 1 (2015): 155.

E. MacKinlay. Ageing and Spirituality across Faiths and Cultures. Philadelphia: PA: Jessica Kingsley Publishers, 2010.

Elviandri, et al. "The Formulation of Welfare State: The Perspective of Maqâshid al-Sharı̂Ah." Indonesian Journal of Islam and Muslim Societies 8, no. 1 (2018): 117-46. https:// doi.org/10.18326/ijims.v8i1.

Fakruddîn al-Râzi. Tafsîr Mafâtih al-Ghayb, . Beirut: Dâr al-Kutub al-'Ilmiyyah, 2000.

Hamzah, Iffat Wishâl. Sîrah 'Umar Ibn 'Abd al-'Azîz Khamis al-Khulafâ' al-Rasyidîn. Beirut: Dâr ibn Hazm, 1998.

Hasan, Md. Nazmul, and Md. Mozammel Hoque. "Influence of Sound from the Words of Human Beingwith Special Reference to Al-Quran (31:19)." International Journal of Islamic Thought 7 (2015): 72.

Ibn Ajibah, Ahmad Ibn Muhammad al-Mahdi. Al-Bahrr Al-Madîd. Beirut: Dâr al-Kutub al'Ilmiyyah, 2002.

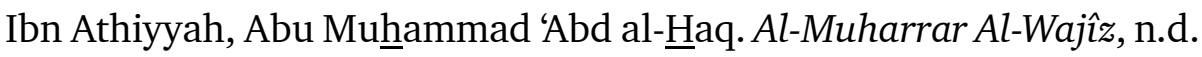

Ismail, Abir Mohamad. "Care in Practice: Negotiations Regarding Care for the Elderly in Multigenerational Arab Muslim Families in Denmark." Contemporary Islam, January 2021. https://doi.org/10.1007/s11562-020-00458-8.

Kodir, Abdul. "Konsep Manusia Dalam Al-Qur'an Sebagai Dasar Pengembangan Pendidikan." UIN Jakarta, 2007.

Kusmana. “The Qur'an, Woman and Nationalism In Indonesia: Ulama Perempuan's Moral Movement." Al-Jami'ah: Journal of Islamic Studies 57, no. 1 (June 2019): 83-116. https:/ /doi.org/10.14421/ajis.2019.571.83-116.

M. Djidin, and Sahiron Syamsuddin. "Indonesian Interpretation of the Qur'an on Khilâfah The Case of Quraish Shihab and Yudian Wahyudi on Qur'an 2: 30-38." Al-Jâmi'ah: Journal of Islamic Studies 57, no. 1 (2019): 155.

Majma, Majallah. "Bab Huquq As-Suyukh Wa Al-Musinnin Wa Wajibatuhum." Al-Fiqh Al-Islami OKI 12 (n.d.): 1811.

Mohd Nasir. "Tarbiyah Al-Âdâb 'inda al-Ulamâ' al-Qadîmah: Tahlîl Afkâr al-Mâwardî Fî al-Tarbiyah al-Akhlâqiyah." MIQOT: Jurnal Ilmu-Ilmu Keislaman 39, no. 1 (2015): 176.

Mukhtarom, Asrori, Ety Kurniati, and Desri Arwen. "Pendidikan Kewarganegaraan Dalam Perspektif Al-Qur'an'." MIQOT: Jurnal Ilmu-Ilmu Keislaman 43, no. 1 (2019): 7-8.

"Old Age Ana Elderly Care An Islamic Perspective," 2021.

Qari, Al-Mulla Ali. Mirqât al-Mafâtih Syarh Misykat al-Mashâbih, n.d.

“"Satan Is a Real Enemy “'Aduwun Mubîn” Is Mentioned Seven Times in the Qur'an and Three Times Begins with the Sentence, 'lâ Tattabi'û: Do Not Follow,' Q.S. al-Baqarah/2: 168, 208, Q.S. al-An'âm/6: 142, Q.S. al-A'râf/7: 22, Q.S. Yûsuf/12: 5, and Q.S. Yâsîn,” n.d. 
MIQOT Vol. 45 No. 1 January-June 2021

Shihab, Quraish. Tafsir Al-Mishbah. Jakarta: Lentera Hati, 2002.

Stapa, Zakaria. "Malay-Muslim Identity in the Era of Globalization." International Journal of Islamic Thought 10, no. 1 (December 2016):55-67.https://doi.org/10.24035/ijit10.2016.006.

T. Ambali, Taiwo. "Social and Economic Foundations of Community Education for Peace in Islam." International Journal of Islamic Thought 11, no. 1 (May 2017): 52-58. https:/ /doi.org/10.24035/ijit.11.2017.006.

Thanthâwî, Muhammad Sayyid. Al-Tafsîr al-Wasîth. Kairo: Dâr Nahdhah Mishr, 1997.

Wahyudi, Yudian. Khalifah and Khilafah in the Context of the NKRI Based on Pancasila. Jakarta, 2018.

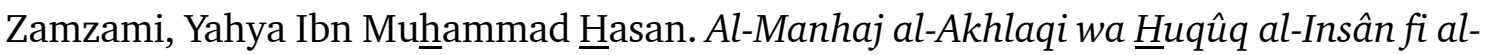
Qur'ân al-Karîm, n.d. 